\title{
EFFECT OF SOME TREATMENTS ON THE QUALITY AND LOWRING COOKING TIME OF BROAD BEAN (Vicia faba)
}

\author{
Okba M. A. \\ Food Technol. Res. Inst., Agric. Rec. Cent., Egypt
}

\begin{abstract}
This study was carried out to evaluate the effect of different treatments on the hardening procedures as well as to improve the quality of broad bean or horse bean (Vicia faba L.). Two broad bean or horse bean (Vicia faba $L$ ) varieties were seeded in Sakha Agricultural Research Station, A.R.C for 2014 season. Three hardening procedures were used ssoaking in acetate buffer, $\mathrm{pH} 4.1$ at $37^{\circ} \mathrm{C}$ for $5 \mathrm{~h}$; storage at $37^{\circ} \mathrm{C} 100 \%$ relative humidity $(\mathrm{RH})$ for 28 days and storage at $31-33^{\circ} \mathrm{C} 76 \% \mathrm{RH}$ for 120 days $\}$ to have seeds in a hardto-cook (HTC) state. The adverse effects of HTC conditions were practically eliminated by soaking seeds in salt solutions $\left(1 \% \mathrm{NaC} 1+0.75 \% \mathrm{NaHCO}_{3}\right.$; and $0.75 \% \mathrm{NaHCO}_{3}$ ) instead of only water. Ultra structural changes of cotyledon cells from fresh, HTC and softened seeds were observed. Results of this study may be used for the development of a technological procedure to utilize properly HTC beans generated by un-efficient storage systems.
\end{abstract}

Key words Treatment, quality, Lowering cooking, Broad bean.

\section{INTRODUCTION}

Broad bean or horse bean (Vicia faba L) are one of the key components of the diet in Latin America. Storage under adverse considered of high temperature and high humidity renders them susceptible to a hardening phenomenon, also known as hard-to-cook (HTC) defect. Broad bean with this defect are characterized by extended cooking times for cotyledon softening, are less acceptable to the consumer and are of lower nutritive value (Molina et al., 2013). The HTC causes significant post-production losses of this particular legume. The HTC is thought to result from changes in the middle lamella/cell wall complex that inhibit cell separation (Rockland and Jones, 2014), but the mechanisms are still unknown. Phytic acid chelates divalent cations $(\mathrm{Ca}, \mathrm{Mg})$ and prevents their cross linking with pectin, thereby facilitating cell wall dissolution during the cooking process. Invariably, soaking seeds in phytic acid or ethylenediaminetetracetic acid solutions, suggesting similarity of their chelating effects (Kon and Sanshuk, 2011) can reduce bean seeds having reduced levels of phytic acid take longer to cook, and this effect. Phytic acid (myo-inositol hexaphosphoric acid), the natural reservoir of seed phosphorus, has been implicated in influencing the cooking quality of legumes (Mattson et al., 2012). Another role of 
phytic acid in the HTC defect has been obtained with studies on phytase, which dephosphorylates this acid and reduces its chelation potential, allowing enhanced cross-linking of pectic substances in the middle lamella. The resultant $\mathrm{Ca}$ and $\mathrm{Mg}$ pectates do not dissolve readily on heating, restricting cell separation and thus producing hardening. The activity of phytase has been reported to increase during storage of bean at high temperatures and humidity. Heat treatments of pinto beans for 15 min in boiling water retarded their rate of hardening, apparently due to denaturation of phytase (Vindiola et al., 2010).

Depending upon conditions, the HTC state usually appears after months of seed storage. Following observations that the $\mathrm{pH}$ of soaking water affected the cook ability of peas (Paredes-Lpez et al., 2014) suggested a chemical test, which detects the HTC tendency of bean cultivars in only hours. On the other hand, (Rockland and Metzler, 2009) proposed soaking Broad bean in food grade salts to overcome the HTC phenomenon. Other workers (Silva et al., 2011 and Elias et al., 2014) have studied the efficacy of soaking solutions to facilitate the cooking step. However, information is still required in the hardening and softening effects of broad bean seeds.

This study was performed to compare the effect of soaking solutions on the cooking quality of broad bean, following by hardened by a chemical method and by storaging under adverse conditions.

\section{Materials:}

\section{MATERIAL AND METHODS}

A- Broad bean or horse bean samples cultivars used for this study (Vicia faba L., cv. Sakha 1 and Sakha 2), very well accepted by consumers because of their highly desirable sensory attributes, were sown in plots at the experimental farm of Sakha Agricultural Research Station, Agriculture Research Center, Egypt. Mature seeds were collected about 45 days after flowering. Broad bean were cleaned and kept in tightly sealed containers at $4^{\circ} \mathrm{C}$ until used.

B- Chemicals used in this study were bought from Elgomhoria Chemical Company, Tanta, Egypt.

Methods:

\section{Moisture content, water activity and Hunter color}

Moisture content was determined by drying samples in an oven with forced air, according to the procedure of AACC, (2000). Water activity was measured in a Rotronic Hygroscop DT apparatus (Rotronic Instr. CO., Huntington, NY) at $25^{\circ} \mathrm{C}$ samples of about $3 \mathrm{~g}$ reached equilibrium at $30 \mathrm{~min}$ or less. Surface color of broad bean was determined using a Hunter-Lab D25-L Color Difference Meter (Hunter 
Associates, Inc., Reston, VA). $L$ (zero = black, $100=$ white); $a$ (+values $=$ red, - values $=$ green $)$ and $b(+$ values $=$ yellow - ,values $=$ blue $)$ were recorded. The $L, a$ and $b$ values of a white standard tile used as reference were $91.2,-1.0$ and -1.7 , respectively according to the procedure of (Rivera et al., 1986). Total color difference $(\Delta \mathrm{E})$ was calculated from the previous Hunter parameters as follows:

$$
\Delta E=(\Delta L)+(\Delta a)+(\Delta b)
$$

Where $\Delta L=L$ std $-L$ sample; $\Delta a=a$ std - a sample; and $\Delta b=b$ std $-b$ sample.

\section{Hardening procedures:}

Two broad bean varieties (Sakha 1 and Sakha 2) and three hardening procedures were performed according to the procedure of ParedesLpez et al. (2014) and Reyes-Moreno, (2008) were used as follows:

\section{Chemical treatment:}

Samples of sixty seeds were soaked in $120 \mathrm{ml} 0.1 \mathrm{M}$ acetate buffer, $\mathrm{pH} 4.1$, at $37^{\circ} \mathrm{C}$ for $5 \mathrm{~h}$. This was termed hardening procedure (HP) 1.

\section{Storage treatments:}

Portions of $500 \mathrm{~g}$ each were stored in two controlled environments:

- HP 2- high temperature, extreme value of relative humidity $(\mathrm{RH})$, and short storage time $\left(37^{\circ} \mathrm{C} 100 \% \mathrm{RH}\right.$ for 28 days).

- HP 3- intermediate temperature, high $\mathrm{RH}$ and long storage time $\left(31-33^{\circ} \mathrm{C} 76 \% \mathrm{RH}\right.$ for 120 days).

\section{Water absorption}

Water absorption patterns to Sakha 2 varity were determined according to a procedure described by Paredes-Lpez et al. (2011) with minor variations. Before the determination, broad bean were taken to the same moisture content $(9.0 \%)$. Portions of seeds were separated in two halves along the longitudinal axis with the help of a blade. Whole and separated seeds were soaked in four volumes of distilled water at $25^{\circ} \mathrm{C}$. Imbibition was measured hourly during the first $4 \mathrm{~h}$ soaking period and every two hours during the following $20 \mathrm{~h}$. Samples were removed, drained, blotted and weighed. The increase in weight was reported as water absorption per $100 \mathrm{~g}$ of dry weight.

\section{Soaking solutions}

For softening purposes the procedure Rockland and Metzler (2009) and Elias et al. (2014) whole seeds were soaked at $25^{\circ} \mathrm{C}$ for 12 $\mathrm{h}$ in four solutions, $\mathrm{A}, \mathrm{B}$ or $\mathrm{C}$ with the following composition:

Solution $A=$ distilled water.

Solution $\mathrm{B}=1 \% \mathrm{NaC} 1+0.75 \% \mathrm{NaHCO} 3$ in distilled water.

Solution $\mathrm{C}=0.75 \% \mathrm{NaHCO} 3$ in distilled water.

\section{Cooking quality}


Mattson et al., (2012) and Reyes-Moreno, (2008) was used to test twenty-five seeds at a time. Cooking time, is the meantime, over three replications, when fifteen of the broad were cooked, as indicated by plungers dropping and penetrating individual beans. The $60 \%$ cooked point corresponds to the sensorily preferred degree of cooking (Paredes-Lpez et al., 2014).

\section{Light microscopy}

Fresh broad and those hardened by the chemical and storage procedures were soaked in four volumes of solution $\mathrm{A}$ (distilled water), or solution $\mathrm{B}(1 \% \mathrm{NaC} 1+0.75 \% \mathrm{NaHCO} 3)$ at $25^{\circ} \mathrm{C}$ for $12 \mathrm{~h}$. All seeds were decanted, washed and then cooked in of boiling distilled water for 60 min. longitudinal segments $(1 \times 3 \mathrm{~mm})$ of the inner part of cotyledons were used for these studies. Samples were fixed in phosphate buffered $(0,1 \mathrm{M}, \mathrm{pH} 7.4) 3 \%$ glutaraldehyde for $5 \mathrm{~h}$ at $4^{\circ} \mathrm{C}$. Fixed samples were washed overnight in $0.25 \mathrm{M}$ sucrose made up in $0.1 \mathrm{M}$ phosphate buffer. Post-fixation was performed in $2 \%$ osmium tetroxide in $0.1 \mathrm{M}$ phosphate buffer at $4^{\circ} \mathrm{C}$ and washed overnight. After dehydration in ascending ethanol series, infiltration was carried out for $24 \mathrm{~h}$ in a diluted epoxy resin. Then, thin sections were cut and stained with toluidine blue (1\% in $0.1 \mathrm{M}$ sodium borate) and observed under a standard Zeiss photomicroscope (Cfirabez-Trejo, et al., 2010).

\section{RESULTS AND DISCUSSIONS}

The moisture content of fresh samples (8.9-9.3\%) increased significantly after hardening, reaching the highest values (22.7-23.3\%) under the hardening procedure (HP) 1 (soaking in acetate buffer at $37^{\circ} \mathrm{C}$ for $5 \mathrm{~h}$ ) (Table 1). As expected, all hardening procedures enhanced water activities. It should be noted that once stored broad beans reach water activities above 0.650-0.675, the deteriorative effects of hardening are evident, probably due to the activation of phytase (Rockland and Jones, 2014) and other enzymes. However, this speculation requires to be investigated. Stored samples tested here showed water activities over the cited range. Remarkable modifications were observed in Hunter color for both Sakha 1 and Sakha 2 varieties, especially under HP 2 (storage at $37^{\circ} \mathrm{C} 100 \% \mathrm{RH}$ for 28 days) and $\mathrm{HP} 3$ (storage at $31-33^{\circ} \mathrm{C} 76 \% \mathrm{RH}$ for 120 days). The two varieties had a reduction in the $L$ value, except in HP 1 , meaning a loss of color lightness. Also, the total color difference $(\Delta \mathrm{E})$ parameter related to the standard used was larger for the stored seed than for the fresh sample, except again in HP 1; these changes reflect the effects of color deterioration. The different trend in color, as assessed by $\mathrm{L}$ and $\Delta \mathrm{E}$ parameters, followed by stored beans under HP 1 might be due to a leaching effect of pigments during the soaking period involved in this test. 
Table 1: Changes in moisture, water activity and color of hard-to-cook beans at the end of the storage period ${ }^{a}$

\begin{tabular}{|c|c|c|c|c|c|}
\hline \multirow{2}{*}{\multicolumn{2}{|c|}{$\begin{array}{l}\text { Variety/hardening } \\
\text { procedure (HP) }\end{array}$}} & \multirow{2}{*}{$\begin{array}{c}\text { Moisture } \\
(\%)\end{array}$} & \multirow{2}{*}{$\begin{array}{l}\text { Water } \\
\text { activity }\end{array}$} & \multicolumn{2}{|c|}{ Hunter color } \\
\hline & & & & $L$ & $\Delta E$ \\
\hline \multirow{4}{*}{ Sakha 1} & Fresh (control) & 8.9 & 0.599 & 56.9 & 40.9 \\
\hline & HP 1 & 22.7 & 0.911 & 54.6 & 39.1 \\
\hline & HP 2 & 21.1 & 0.810 & 42.9 & 51.8 \\
\hline & $\mathrm{HP} 3$ & 14.9 & 0.802 & 36.2 & 60.1 \\
\hline \multirow{4}{*}{ Sakha 2} & Fresh (control) & 9.3 & 0.511 & 57.8 & 38.3 \\
\hline & HP 1 & 23.3 & 0.847 & 57.8 & 37.4 \\
\hline & HP 2 & 20.1 & 0.794 & 50.9 & 45.0 \\
\hline & HP 3 & 16.5 & 0.791 & 48.1 & 47.4 \\
\hline \multicolumn{2}{|c|}{$\operatorname{LSD}(0.05)^{c}$} & 1.4 & 0.745 & 0.5 & 0.6 \\
\hline
\end{tabular}

$\mathbf{a}=$ Means of triplicates. $\mathbf{b}=$ Hardening procedures 1,2 and $\mathbf{c}=$ Least significant difference. HP1= soaked in $120 \mathrm{ml} 0.1 \mathrm{M}$ acetate buffer, $\mathrm{pH} 4.1$, at $37^{\circ} \mathrm{C}$ for $5 \mathrm{~h}$. HP2= storage time at $37^{\circ} \mathrm{C}$ in $100 \% \mathrm{RH}$ for 28 days. HP $3=$ storage time at $31-33^{\circ} \mathrm{C}$ in $76 \% \mathrm{RH}$ for 120 days.

Soaking in water produced significant reductions in cooking time for fresh and HTC broad beans of the two used varieties; even after water-soaking, samples stored under HP 1 and HP 3 exhibited remarkably high cooking times (Table 2).

Table 2: Influence of the hardening procedure and soaking solution on the cooking quality of two common bean varieties ${ }^{a, b}$

\begin{tabular}{|c|c|c|c|c|c|}
\hline \multirow{3}{*}{\multicolumn{2}{|c|}{$\begin{array}{l}\text { Variety/hardening } \\
\text { procedure }(\mathrm{HP})^{c}\end{array}$}} & \multicolumn{4}{|c|}{ Cooking time $(\mathrm{min})^{d}$} \\
\hline & & \multirow{3}{*}{$\begin{array}{c}\text { Without soaking } \\
151\end{array}$} & \multicolumn{3}{|c|}{ Soaking solution } \\
\hline & & & A & $\mathrm{B}$ & $\mathrm{C}$ \\
\hline \multirow{4}{*}{ Sakha 1} & Fresh (control) & & 86 & 73 & 58 \\
\hline & $\mathrm{HP} 1$ & - & $>498$ & 69 & 64 \\
\hline & HP 2 & 291 & 196 & 73 & 68 \\
\hline & HP 3 & - & $>551$ & 69 & 133 \\
\hline \multirow{4}{*}{ Sakha 2} & Fresh (control) & 129 & 113 & 56 & 59 \\
\hline & HP 1 & - & $>453$ & 71 & 53 \\
\hline & HP 2 & 283 & 271 & 84 & 68 \\
\hline & HP 3 & - & $>534$ & 66 & 151 \\
\hline
\end{tabular}

$\mathbf{a}=$ Whole seeds were soaked at $25^{\circ} \mathrm{C}$ for $12 \mathrm{~h}$ in four solutions $\mathrm{A}, \mathrm{B}$ or $\mathrm{C} . \mathbf{b}=$ Means of triplicates. $\mathbf{c}=$ Hardening procedures 1, 2 and 3 described under Materials and methods. $\mathbf{d}=$ Time required to reach the point at which $60 \%$ of the beans were cooked. $\mathbf{e}=$ Least significant difference. $\mathbf{H P 1 =}$ soaked in $120 \mathrm{ml} 0.1 \mathrm{M}$ acetate buffer, $\mathrm{pH} 4.1$, at $37^{\circ} \mathrm{C}$ for $5 \mathrm{~h}$. HP2= storage time at $37^{\circ} \mathrm{C}$ in $100 \% \mathrm{RH}$ for 28 days. HP 3= storage time at $31-33^{\circ} \mathrm{C}$ in $76 \% \mathrm{RH}$ for 120 days.

The salt solutions $B$ and $C$ changed dramatically the broad bean texture, which was reflected in much lower cooking times especially for all HTC samples. There were significance differences in the softening effect between solutions B and C; solution B decreased more effectively the cooking time of samples stored under the HP 3.

The use of salts in soaking solutions overcame the HTC state produced by unfavorably storage conditions and even the hardened effect given by the chemical test (HP 1). Results of this study are in general agree with those reported by other workers (Silva et al., 2011 and Elias et al., 2014). The most important differences of this research 
with the cited studies are the use of a simplified and low-cost objective test for determination of cooking time, the development of the HTC state under two different storage conditions followed by the softening treatment, and, for comparison purposes, evaluation of the HP 1.

The HP 1 gives a high correlation in broad bean firmness with that rendered by storage at high temperature and relative humidity and it has broad been suggested to be used in breeding studies (CfirabezTrejo et al., 2010 and Paredes-Lpez et al., 2014) to select materials with reduced tendency to the HTC phenomenon. In view of the trends exhibited by whole and HTC seeds in the water absorption test, it is likely that soaking time in salt solutions may be dramatically reduced without affecting the softening effect. However, it needs to be studied in detail.

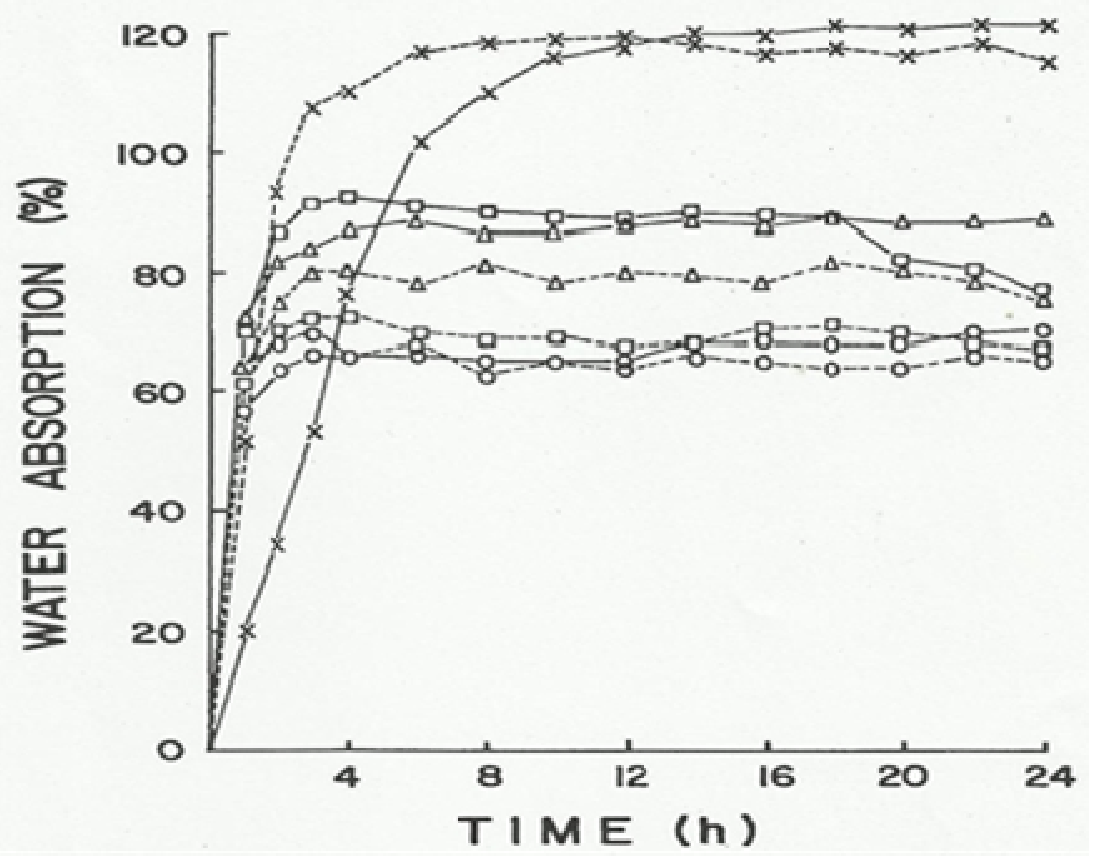

Figure 1: Water absorption of whole and separated seeds Sakha 2 broad beans, where:

) $=$ Whole broad bean seeds. (----) $=$ Broad bean seeds separated. $\mathbf{X}=$ fresh seeds. $\mathbf{O}=$ HTC (hard-to-cook) seeds by soaking in $0.1 \mathrm{M}$ acetate buffer, $\mathrm{pH} 4.1$, at $37^{\circ} \mathrm{C}$ for $5 \mathrm{~h}$ [hardening procedure (HP) 1]. $\Delta=\mathrm{HTC}$ seeds by storage at $37^{\circ} \mathrm{C} 100 \% \mathrm{RH}$ for28 days (HP 2). $\square=\mathrm{HTC}$ seeds by storage at $31-33^{\circ} \mathrm{C} 76 \% \mathrm{RH}$ for 120 days (HP 3).

Figure (1) shows water absorption of whole and separated seeds Sakha 2 broad beans. Saturation level was reached at about $12 \mathrm{~h}$ soaking for fresh samples, whereas for hardened seeds stored under 
the three HP this was attained at $4 \mathrm{~h}$ or less. Within the first $12 \mathrm{~h}$ soaking, the lower rate of absorbed water for intact fresh seeds may be ascribed to the retardant effect played by the seed coat.

The decrease in water absorption capacity of HTC seeds was evident, being more pronounced for those under the HP 1. Interestingly, all the intact HTC seeds exhibited higher water absorption, than the corresponding separated halves, since absorbed water was partially retained between the seed coat and cotyledons as observed previously (Paredes-Lpez et al., 2014). Trends in water absorption followed by intact and separated seeds, either fresh or HTC, belonging to Sakha 1 variety were similar to those described here. (Varriano-Marston and Jackson 1981) using radioautogram of HTC intact and decorticated beans showed that hilum was an important rate-limiting barrier to water absorption. It was found that water uptake by cotyledons of stored beans was affected by structural changes. Results of the present study suggest that, besides the limiting role that hilum may play, changes of biochemical and/or physicochemical nature are occurring in cotyledons of stored seeds, giving as a result a lower water uptake capacity.

Cotyledons from fresh, HP 1, HP 2 and HP 3 Sakha 2 beans, soaked in water (samples A) or soaked in $\mathrm{NaC} 1+\mathrm{NaHCO} 3$ (samples $B)$, then cooked in water for the same time, were observed by light microscopy (Fig. 2). Samples A exhibited starch granules in a gelatinized-like state. The protein bodies, compared to those in previous studies (Palma-Tirado, 1990 and Cfirabez-Trejo et al. 2010), were apparently degraded and modified to a highly-stained amorphous mass (black areas). It was evident that middle lamella of all stored cotyledons in samples was narrower than that of fresh seeds. These results are in agreement with the observations of some workers (Varriano-Marston and Jackson 1981; Cfirabez-Trejo et al. 2010 and Paredes-Lpez et al. 2014) who found that cooking did not produce cell separation in the cytoplasm of stored beans as compared to fresh samples. The strong adhesion between cells for hardened seeds might partially explain the reduced water uptake and consequently the lower cooking quality of these samples.

The effect of soaking fresh and HTC seeds in the chemicals of solution B is appreciated in the microphotographs of Fig. 2 (samples B). The appearance of middle lamella was outstandingly different to that of samples A. All specimens showed a clear separation of cotyledon cells and had a significantly reduced cooking time (Table 2) compared to the corresponding samples soaked just in water. On the other hand, the HTC seeds generated by the chemical procedure (HP 1) did not appear, at least ultra-structurally, remarkably different to those hardened by storage (HP 2 and HP 3). In general, ultra structural 
changes in Sakha 1 seeds were very much similar to those revealed by Sakha 2 .

In summary, hardened beans by chemical and storage procedures may be remarkably softened by soaking in $\mathrm{NaC} 1+$ $\mathrm{NaHCO} 3$ or just in NaHCO 3.

Thus, the cooking time of HTC seeds is considerably reduced. These treatments may constitute the technical basis for the development of a technological procedure to use, at an industrial scale, hardened beans generated by the lack of efficient storage systems in developing countries. Other workers (Silva et al., 2011 and Elias et al., 2014) reported that soaking in chemical solutions, to soften bean texture, renders an acceptable product from the sensory and nutritional point of view. However, studies are needed along this line with the common bean varieties used here.

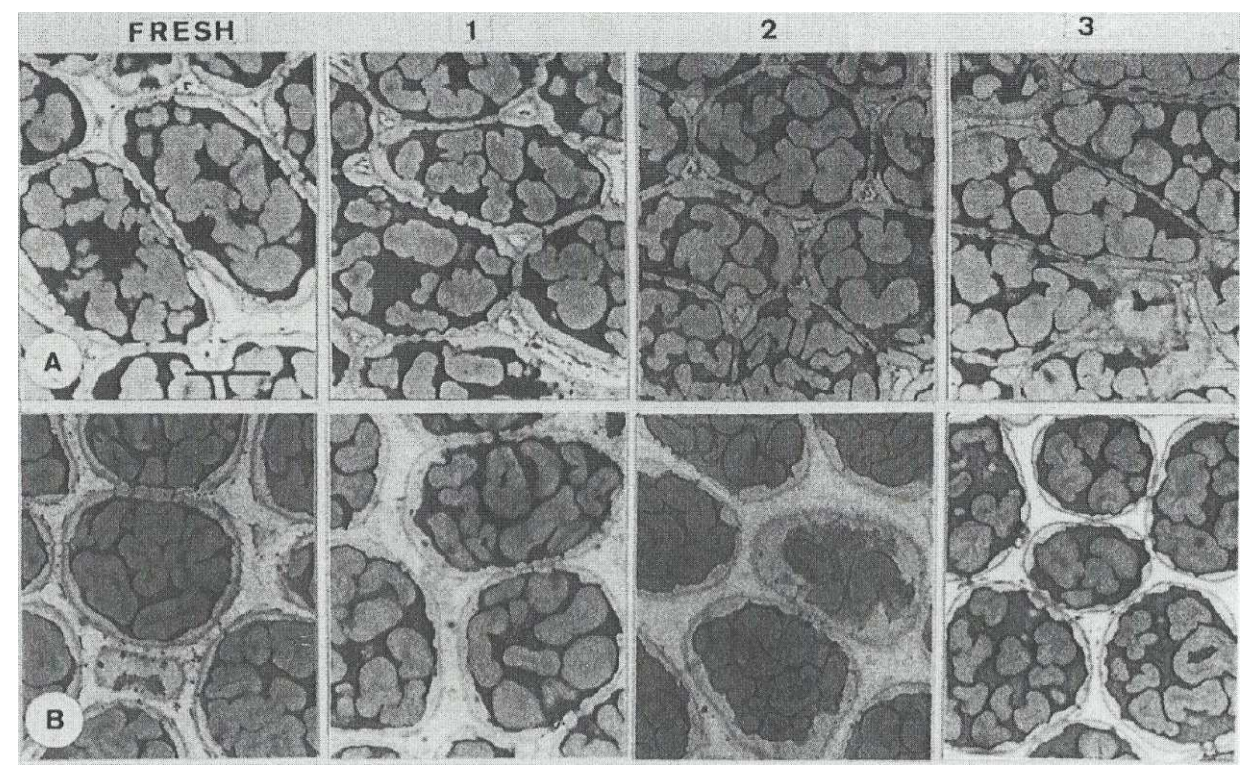

Fig. 2. Microstructure of cotyledon cells from cooked bean seeds of Sakha 2 variety using light microscopy

Samples A were soaked at $25^{\circ} \mathrm{C}$ for $12 \mathrm{~h}$ in four volumes of distilled water, decanted and cooked for $60 \mathrm{~min}$. in four new volumes of distilled water. Samples B were soaked at $25^{\circ} \mathrm{C}$ for $12 \mathrm{~h}$ in $1 \%$ $\mathrm{NaCl}+0,75 \% \mathrm{NaHCO} 3$ (solution $\mathrm{B}$ ), decanted and cooked for $60 \mathrm{~min}$. in four new volumes of distilled water. Seeds used in these experiments were Fresh; HTC (hard-to-cook) by soaking in $0.1 \mathrm{M}$ acetate buffer, $\mathrm{pH} 4.1$, at $37^{\circ} \mathrm{C}$ for $5 \mathrm{~h}$ [hardening procedure (HP 1)]; HTC by storage at $37^{\circ} \mathrm{C}, 100 \% \mathrm{RH}$ for 28 days (HP 2) and $\mathrm{HTC}$ by storage at $31-33^{\circ} \mathrm{C}, 76 \% \mathrm{RH}$ for 120 days (HP 3). (Bar size $=50 \mu \mathrm{m})$. 


\section{REFERENCES}

AACC (2000). Approved methods of the AACC, $8^{\text {th }}$ ed. St. Paul, MN: AACC, USA.

Cfirabez-Trejo, A.; Paredes-Lopez, O. and Reyes-Moreno, C. (2010). Microstructure

of cotyledon cells from hard-to-cook common beans. Starch/St/irke 41:335-339.

Elias, L.; Leon L. and Bressani, R. (2014). Use of salt solutions to decrease cooking

time of the hard-to-cook beans. In: Proceedings of the Third Workshop held in

Termas de Panimavida, Chile. Ottawa, Canada: IDRC, pp. 104-121.

Kon, S. and Sanshuk, D. (2011). Phytate content and its effect on cooking quality of beans. J Food Process Preserv 5:169-176.

Mattson, S.; Akerbergm E.; Eriksson, E.; Koulter-Anderson, E. and Vahtras, K.

(2012). Factors determining the composition and cookability of peas. Acta

Agric Scan1:40-61.

Molina, M.; Fuente L. and Bressani, R. (2013). Interrelationships between storage,

soaking time, nutritive value and other characteristics of the black bean

(Phaseolus vulgaris). J Food Sci 40:587-591.

Palma-Tirado, M. (1990). Efecto del remojo en soluciones salinas y de la cocci6n

sobrela microestructura del frijol comfin (Effect of soaking in salt solutions and

cooking on the micro-structure of common bean). BSc thesis, $U$. Irapuato, CIEA-

IPN-Inst. Tecnol. De Celaya, Mexico.

Paredes-Lpez, O.; Maza-Calvifio, E. and Gonzfilez-Castafieda, J. (2011). Effect of

the hardening phenomenon on some physicochemical properties of comon bean.

Food Chem. 31:225-236.

Paredes-Lpez, O.; Reyes-Moreno, C.; Montes-Rivera, R. and CtrabezTrejo (2014).

Hard-tocook phenomenon in common beans - influence of growing location and

hardening procedures. Int. J. Food Sci. Technol. 24:535-542.

Reyes-Moreno, C. (2008). Influencia de la localidad de siembra sobre la calidad de

coccion y propension al endurecimiento del frijol comfin (influence of growing 
location on the cooking quality and tendency to hardening of common bean). MSc thesis, U. Irapuato, CIEA-IPN, Irapuato, M6xico Paredes-Lpez O.; Montes.

Rivera, R.; Gonzlez-Castafieda, J. and Arroyo-Figueroa, M. (1986). Comparison

of selected food characteristics of three cultivars of bean Phaseolus vulgaris. J.

Food Technol. 21:487-494.

Rockland, L. and Jones, F. (2014). Scanning electron microscope studies on dry

beans. Effects of cooking on the cellular structure of cotyledons in rehydrated

large lima beans. J Food Sci 39:342-346.

Rockland, L. and Metzler, E. (2009). Quick-cooking lima and other dry beans. Food

Technol. 21(3):344-347.

Silva, C.; Bates, R. and Deng J. (2011). Influence of soaking and cooking upon the

softening and eating quality of black beans (Phaseolus vulgaris). J. Food Sci.

46:1716-1720.

Varriano-Marston, E. and Jackson, G. (1981). Hard-to-cook phenomenon in beans:

structural changes during storage and imbibition. J. Food Sci. 46:1379-1385

Vindiola, O.; Seib P. and Hoseney, R. (2010). Accelerated development of the hard-

to-cook state in beans. Cereal Foods World 31:538-552.

$$
\begin{aligned}
& \text { تأثير بعض المعاملات على جودة وتقليل من وقت طبخ الفول البلدى. } \\
& \text { محمد على بسيونى عقبة الإنة } \\
& \text { معهد بحوث تكنولوجيا الأغذية ـ مركز البحوث عفئ الزراعية ـ مصر }
\end{aligned}
$$

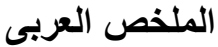

$$
\begin{aligned}
& \text { أجريت هذه الدراسة على صنفين من الفول البلدى (سخا } 1 \text { وسخا 2) اخذاعت من من محصول موسم }
\end{aligned}
$$

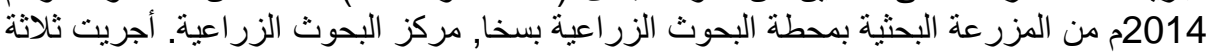

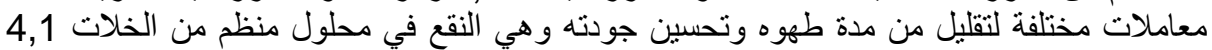

$$
\begin{aligned}
& \text { عH }
\end{aligned}
$$

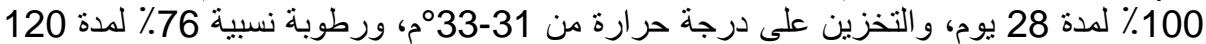

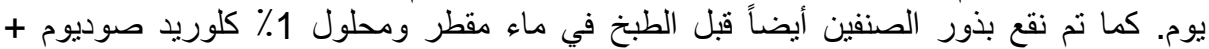

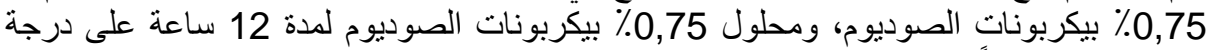

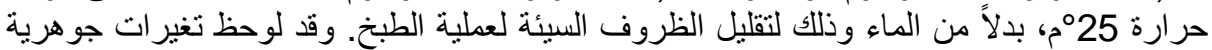

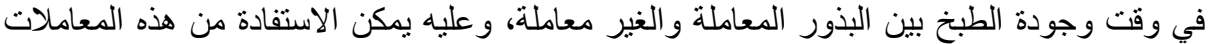

$$
\begin{aligned}
& \text { في تطوير الإجر اءات التكنولوجية المستخدمة في تقليل وقت طهي الفئ الفول وتحسين جودنه. }
\end{aligned}
$$

